\title{
Impacts of Leadership Styles and Organizational Commitment towards Job Performance in the Malaysian Army
}

\section{${ }^{1}$ S. Inderjit, ${ }^{2}$ Kwong, F.W., ${ }^{1}$ Jessica Ong Hai Liaw and ${ }^{1}$ Norlaila Mazura Hj. Mohaiyadin}

${ }^{1}$ Faculty of Defence Studies \& Management, National Defence University of Malaysia, Sungai Besi Camp, 57000 Kuala Lumpur, Malaysia. ${ }^{2}$ Malaysian Army Headquarters, Inspectorate Department, Ministry of Defence, Malaysia.

Correspondence Author: S. Inderjit, Faculty of Defence Studies \& Management, National Defence University of Malaysia, Sungai Besi Camp, 57000 Kuala Lumpur, Malaysia.

Tel: +6019-2281866; E-mail: sinder1866@yahoo.com

Received date: 12 January 2018, Accepted date: 27 June 2018, Online date: 21 July 2018

Copyright: (c) 2018 S. Inderjit, Kwong et al. This is an open-access article distributed under the terms of the Creative Commons Attribution License, which permits unrestricted use, distribution, and reproduction in any medium, provided the original author and source are credited.

\begin{abstract}
The purpose of this research is to identify the factors contributing towards the job performance of the Senior Non-Commissioned Officers (SNCOs) in the combat support corps of the Malaysian Army from the perspective of Junior Senior Non-Commissioned Officers (JNCOs). Job performance of the SNCOs was conceptualized to comprise of organizational commitment and leadership style. The research is premised on identifying whether organizational commitment has an influence as the mediating factor between leadership style and job performance of SNCOs. The research was based on post-positivist philosophy. Quantitative approach and non-experimental survey was used for the research. The data consisting of 548 respondents were collected from soldiers of rank of corporal and below i.e. Junior Non-Commissioned Officers (JNCOs) from the combat support corps units of the Malaysian Army. The statistical treatment of the data obtained was done by using PLS-SEM in order to determine the plausibility of the data obtained with the hypothesized model of job performance. This research has identified that job performance of the SNCOs in the combat support corps consists of leadership style and organizational commitment. However, the research established that leadership style is not significant to organizational commitment that contributed towards job performance of SNCOs in the combat support corps of the Malaysian Army. Transformational leadership has a more significant relationship that transactional leadership among the SNCOs The research has also determined that there is a significant relationship between organizational commitments with job performance. Nevertheless, there is no mediating role played by organizational commitment for the effect of leadership style on job performance.
\end{abstract}

Key words: Leadership Style, Transformational Leadership, Transactional Leadership, Organizational Commitment

\section{INTRODUCTION}

The military organizational culture is a predominant force. Its influence instills, molds, governs, and propagates beliefs, mindsets, attitudes, and behaviours, both individually and collectively [1]. It establishes and perpetuates a shared frame of reference and shared reality encompassing all aspects of the military way of life and soldiers' professional and personal lives. Much has been written on military job performance [1-3], particularly on the issues and challenges which are affecting soldiers' performance. But what is performance in the context of military? Commanders must understand true performance from their soldiers so that they are prepared in all situations especially in combat needs. Industrial-organizational psychologists have studied "performance" and their research ascertained that performance is "something that people actually do and can be observed which include only those actions or behaviours that are relevant to the organization's goals" [4]. Borman \& Motowildo [5] further distinguished the perception of performance to comprise of task performance and contextual performance which are both significant for organizational efficiency and effectiveness. Performance is commonly classified as maximum and typical performance [6]. The importance of job performance in the military requires soldiers to be combat prepared as an individual and towards collective approach working together in teams that enable them to survive and sustain in war zone areas. For improved job performance, proper structured training with current doctrines and concepts have to be planned and implemented. Job performance requires the full complement of equipment, infra-structure, processes, skills, and job levels that are assigned to an organization to increase their overall organization performances. Performance of employees affects the growth of the organization. Thus, there is a need of identifying employee's individual job performance. The right leadership style is a fundamental indicator of the organization's performance because the right leadership influences employees' attitude and behaviour. The right attitude of employees is shown though their organization commitment that has an impact on job performance [7]. Empirical findings of research studies specified that organizational performance, job performance and employee commitment are outcomes greatly preferred by corporate leadership and management [8-9]. With the increasing competitive global environment many researchers have agreed that leaders and managers in all organizations could provide assistance in motivating and guide their employees with effective leadership style specifically transformational or transactional leadership [8-11].

BACKGROUND OF STUDY:

In the military, job performance is dependent on the soldier's ability to go beyond what is needed, required, or expected in the performance of their duty. In other words, the soldiers must go beyond the call of duty. Loyalty and commitment are among the two main traits of a soldier in ensuring courage and determination that are showcased in extreme working conditions. Undeniably, these conditions have changed the way military teams function. The main challenge faced on the functioning of the military teams is how could the teams communicate and coordinate tasks under dynamic, high-stress, high demand environments [12]. According to Ying et al. [13], it is fair to say that success depends on good soldiers in the military organization whom are often faced with life or death 
situations during combat. They do not receive extra pay or bonuses premised on merit or achievement. Hardy et al. [14] noted that the typical nature of duties of a soldier in his professional competency is characterized by his personal and individual military competency and skills forged into working collectively as a team. He said that they are often regarded as behaviours that go beyond the call of duty and include volunteering for tasks that are not assigned, providing innovative ideas to improve operations and assisting peers and commanders with job-related assignments. Such altruism is neither prescribed nor required but they contribute to the smooth functioning of the organization. According to Amna et al. [15], such performance is theorized to originate from a social exchange relationship between the employee and the organization. The aspects described above are of concern in the current study of job performance of the personnel in the Malaysian Army.

Faced with the demanding, all-consuming obligations, commitments, and sacrifices required by the Army, soldiers experience the challenge of balancing military work requirements and lifestyle with family and personal needs [1]. In the military service, soldiers are expected to understand that they are subjected to organizational practices, norms and values which require a high sense of obligation, loyalty and duty [16]. As such, ccommanders must be able to understand the true performance from their soldiers. They have to be prepared in all situations especially for combat that are led by leaders with different leadership style affecting the loyalty, espirit de corps, acting beyond the call of duty, selfless dedication, heroism, commitment and loyalty among the soldiers [5]. Similarly, Tremblay [17] pointed out that the completeness of a soldier requires their commitment to their unit which is influenced by their commanders' leadership style. It was also highlighted by Kane \& Tremble [18] that leadership style has a major role in the performance of a soldier especially in the combat zone. He also stressed the need to acknowledge soldier's military commitment in enhancing job performance through the leadership style. There is no research conducted specifically in the military on the relationship between leadership style, organizational commitment and job performance. Also, none of the research has focused on a particular group of middle managers i.e. Senior Non-Commissioned Officers (SNCOs). NCOs in this research refers to members of the military organization who are not commissioned officers and are subordinates to a military commander. SNCOs are considered the primary link between enlisted personnel and the commissioned officers in a military organization. Their advice and guidance is particularly important for junior officers, who begin their careers in a position of authority but generally lack practical experience. In Malaysian Army their rank includes Sergeant, Staff Sergeants and Warrant Officers. Junior NCOs are divided into three categories. Private, Lance corporals (including lance bombardiers) and corporals (including lance sergeants, bombardiers, and lance corporals of horse) are junior NCOs.

Similarly, research on the perspective of commitment and leadership style of middle managers in particular noncommissioned officers in the military has not been studied. Thus, this research hinges on the theory that suggest transformational leadership, more than transactional leadership, has a higher significant relationship effect on employees' outlooks towards their job and job environment which eventually affects their job performance [19]. This aspect although has been proven but has never been implemented or tested in the SNCOs of the Malaysian Army. Additionally, the leadership style in the military has been instrumental in the performance of soldiers both individually and collectively [20]. The leadership style and the organizational commitment of soldiers is often related and has an influence to job performance but this never been proven. This is important since the leadership style of SNCOs who provides the bridge as the middle managers in the hierarchical rank structure of the military structure. Although plenty of research has been done on leadership, very few of the published research works used empirical methods to study the influence or effect of different leadership styles on employee's organizational commitment on a particular task over time leading to their job performance especially in the military environment.

Dewettick et al. [21] identified that there are many factors that affect job performance, employee interaction, job commitment, leadership and managerial styles in the context of an organization which eventually leads to organizational performance. It could be seen that the factors of organizational behaviour were often used in the study of both group and individual performance and activity within an organization [22]. In this regard; Chan, Soh \& Ramaya [20] identified that there is a need to understand soldiers' loyalty in terms of organizational commitment to ensure the performance of soldier is consistent with their working environment. In the military environment, middle managers like the SNCOs plays a major role in ensuring hierarchical management communication and link between top to down and vice versa. As pointed out by Huy [23], ideas of middle managers are often overlooked. As such, it is paramount for this study to provide an outcome that would allow the top military management to shape and lead the SNCOs into a bigger role in their designation as middle managers to assist military officers in accomplishing organizational commitments for effective job performance.

This research provides the top management in the military hierarchy a fundamental platform on leadership style that can encourage optimum staff performance besides quantifying the role of organizational commitment. This is significant in the middle managers who are the SNCO's and their role towards the higher management in terms of officers of the Malaysian Army which will be determined by JNCOs. From the policy perspective, the research is expected to contribute further understanding in leadership style and behaviour of SNCOs that are essential for military doctrine in the Malaysian Army for current and potential military commanders. Further understanding on leadership style and work commitment that are important to SNCOs through appropriate academic programs would enhance human resource management abilities among the SNCOs in the Malaysian Army.

\section{The Concept and Meaning of Job Performance:}

Job performance is a very common term but has not been defined comprehensively even in industrial and organisational psychology. It is one of the branches of psychology. In general, job performance is viewed as how an individual performs his/her job in a better way Li [24]. Job performance is not only confined to industrial and organisational psychology, but also associated with Human Resource Management. The concept is generally viewed as how an individual performs his job and the improvements needed in the way he performs in his job. Though, there is a perplexity over the exact definition of job performance, it is considered a highly crucial factor in the context of organisational outcomes and success. The most common and widely acceptable theory over job performance is derived from the work of Campbell et al. [25] and Campbell, McCloy, Oppler \& Sager [4]. In psychological point of view, the authors explain the level of job performance varies from person to person. In fact, it is a something that is done by a single individual. In this way, the job performance can be differentiated from more encompassing constructs like the performance. Job performance is multifaceted and can be measured, but it is complicated by the fact that what counts for job performance is itself complex, changes over time and situation, and consists of multiple magnitudes [26]. The challenge of defining job performance remains an abstract concept which is publically created. There are many judgement calls required when it is being operationalized even when it relies on apparently 'objective' measures such as behavioural counting, organizational records and the like Murphy \& Cleveland [27]. Performance is a behaviour which is shaped by the employee himself or herself [4]. This conception describes the performance as something different from outcomes. Though, outcomes are the results produced by the performance of a person, there are some other factors which have a significant role in it. In short, outcomes are not only determined by the actions or behaviours of employees without considering other influential elements. Exceptions were given in the Campbell presented idea under which he describes performance as behaviour. According to his clarification, performance cannot be directly measured from the actions of an individual. In fact, the performance can comprise several mental productions e.g. decisions or answers. It is required to keep the performance under the control of an individual, regardless of whether the performance of interest is behavioural or mental.

\section{Leadership Style:}

The concept of leadership has been developed and has propagated in almost all areas of the public and private sectors, such as in field of education, health military and defence, etc. This is because it has been recognised globally by scholars that leadership (its effectiveness) does indeed produce performance. It is essential for the leaders not only to take part in the organizational or certain sectional progress targets but also to participate and manage the practices of the subordinates in order to encourage them to achieve required goals set for their job performance [28]. Organisational performance has been the centre of attention of the scholars for the last 25 years [29]. Coupled with organisational commitment is the element of leadership style in assisting the organizations for advancing and improving their performing skills. With the passage of time the subject of suitable leadership models, styles and attitudes has been given more attention from the managers as well as the scholars. Thus, it can be seen that continuous arguments have been going on about the impacts of the leadership styles on the performance of the organizations. 
Transformational leaders tend to have more initiative in several distinctive manners. They have a positive response towards the growth of an organization instead of merely focusing on performance. Growth and development encompass the progress of skills, encouragement, behaviours and beliefs. Transformational leadership is a style of leadership that inspires followers to involve, commit, and share their vision and goals for the organisation; encourages followers to be innovative in solving organizational problems; and supports followers to have leadership competencies through coaching and mentoring [30]. Transformational leadership can be an important factor that influences employee performance due to idealised influence, individual consideration, inspirational motivation, and intellectual stimulation which are provided by the transformational leaders. Transformational leaders persuade their followers to make efforts for a greater mark of achievements along with greater marks of ethical views and values [31]. It is pertinent to note that Bass \& Avolio [32] have conceptualized transformational leadership as containing four behavioural components, namely: Idealized influence, inspirational motivation, intellectual stimulation, and individualized consideration.

\section{Transactional Leadership:}

Transactional styles of leadership were differentiated from transformational by Burns [33], who is the founder of the Transformational Leadership theory [32]. Burns [33] said transactional leadership is the reaching out of contact with the ultimate purpose of exchanged of valued things with each other. This aspect also involves rewards and reprimands. In a subsequent research by Bass [34], he found that transactional leaders have to detect and explain to subordinates about the role, task requirements, performance expectations and the awarding of rewards and punishment in accordance with performance. Thus, the focus for transactional leaders is mainly on tangible factors which relates to physical and security needs of subordinates. As such, the leader and follower are bounded by the relationship that provides bargaining exchange or reward systems [32,34]. Apart from that, Politis [35] concluded that transactional leaders provide followers with confidence and subsequently motivate followers to achieve desirable performance. In a follow-up study by Bass et al. [36], it was found that followers fulfil the leader's requirement in exchange for praise and rewards or the avoidance of punishment for non-performance or lack of goal achievement. Instead, transactionoriented leaders are more concerned with the accomplishment of the goals. On similar studies by Sadler [37] and later Yukl [38], both the studies concurred that transactional leaders motivate followers by offering some form of satisfaction based on needs such as pay or other rewards in return for work effort. Ivey \& Kline [12] also said that transactional leaders exchange things of value with followers to advance both parties' requirements. This leads subordinates to produce the results that leaders expect. However, on this aspect, it must be noted that some subordinates fulfill leaders' requests because of the exchange or rewards offered by leaders; not because they are devoted to their jobs. This differentiation was proven by Yukl [38] that the exchange process is not likely to produce passion and commitment among followers.

\section{Organizational Commitment:}

Based on the literature on organizational commitment, past research found that organizational commitment refers to an employee's belief in the organization's goals and values, desire to remain a member of the organization and loyalty to the organization [39-41] pointed out that committed employees "identifies with, is involved in, and enjoys membership in, the organization". Studies have also concluded that committed employees are more likely to have higher job performance [42-43]. The studies by Meyer \& Allen [44-45] suggested that commitment in an employee's relationship with an organization can be categorized into three broad themes; that is, commitment is related to affective orientation toward the organization, recognition of cost associated with leaving the organization, and moral obligation to stay in the organization. Also, organizational commitment is viewed as a psychological state that ties employees to their organization [45]. Where else Robbins \&Judge [46] defines commitment as a situation where an individual is an impartial organization as well as the objectives and the desire to maintain its position in the organization. In a more recent study on organizational commitment, Putriana [47] found that organizational commitment are important determinants of job performance. Interestingly, Solinger et al. [48] argued that the three-component model of organizational commitment stated by Meyer \& Allen [44], which has been the dominant model in organizational commitment research, is inconsistent as it combines different attitudinal phenomena with different relationships for focal and non-focal behaviours. However, in recent studies, Fu \& Deshpande [49] and Akdogan \& Demirtas [50] said organizational commitment is a measure of an employee's identification with his or her organization. The study concluded that organizational commitment consists of three elements, namely: a strong belief and acceptance of the goals and values of the organization, willingness to exert considerable effort for the organization, and a strong desire to remain a member of the organization. In other words, members are emotionally attached to their organisation, as they believe in its values and vision.

\section{Theoretical Framework:}

The selection of appropriate theory provided the basis for the research framework of this research. The objectives of the research were based on two perspectives emphasized in this study; the first was to examine the job performance of SNCOs and to determine the leadership style of SNCOs in the combat support corps of the Malaysian Army, from the perspective for the JNCOs. Second, this study was to determine the organizational commitment of SNCOs as the mediating variable towards job performance. Thus, the conceptualization of the research framework of job performance model was based on three main constructs namely; job performance, leadership style and organizational commitment. The research framework of the research is based on Job Performance as the dependent variable, Leadership Style as the independent variable and Organizational Commitment as the mediating variable. The construct of Job Performance is viewed from the dimension of task performance and contextual performance. While leadership style is examined in the aspect of transactional and transformational leadership styles. Finally, the Organizational Commitment construct is looked from the dimension of affective, normative and continuance. This theoretical framework is as shown in Figure 1.

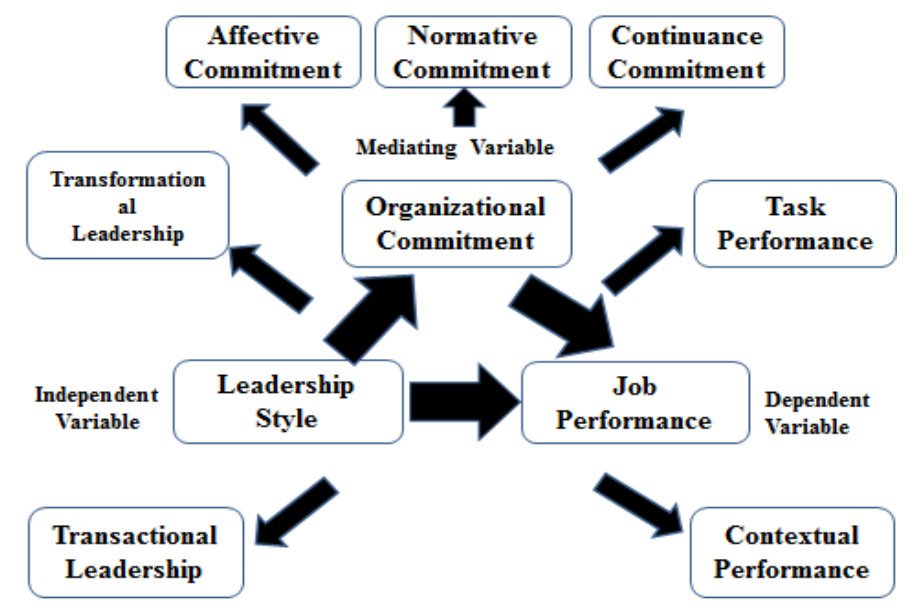

Fig. 1: PLS Algorithm of Job Performance 


\section{METHODOLOGY:}

This study administered four sets of survey instruments for data collection. These instruments are the ranking order of job performance Armed Forces Continuous Survey Questionnaire, the Army-Wide In-Unit Performance Rating Scale (AIPRS) [51], the MLQ Form 5X-Short [32] to describe leadership style and organizational commitment questionnaire using the most widely used global measure i.e. Mowday et al. [52] and the Organizational Commitment Questionnaire (OCQ) developed by Mowday et al. [39] to measure the level of commitment and the relative strength of individuals' identification with organizations. Proportionate stratified random sampling of $n=548$ was used for the sampling in this research. Partial Least Square (PLS) algorithm was used for estimating the PLS path model. The SmartPLS software provided results in the modeling window after the estimation of the model [53]. The PLS-SEM results are the outer loadings and outer weights for the measurement models (organizational commitment and leadership style), the path coefficient for the structural model relationships and the $\mathrm{R}^{2}$ values of the endogenous variables (job performance).

\section{RESULTS AND DISCUSSION}

The results of the path model of Job Performance are as shown in Figure 2. These $\mathrm{R}^{2}$ values represent the amount of explained variance in the construct. The $\mathrm{R}^{2}$ value of 0.403 for the construct of job performance indicates that $40.3 \%$ of job performance is explained by exogenous variables of organizational commitment and leadership style. While $\mathrm{R}^{2}$ values of 0.20 are considered high in disciplines such as consumer behaviour, researchers in success driver studies expect much higher values of 0.75 and above. In scholarly research on marketing issues, $\mathrm{R}^{2}$ values of $0.75,0.50$ and 0.25 for endogenous latent variables can be described as substantial, moderate or weak respectively [54-55].

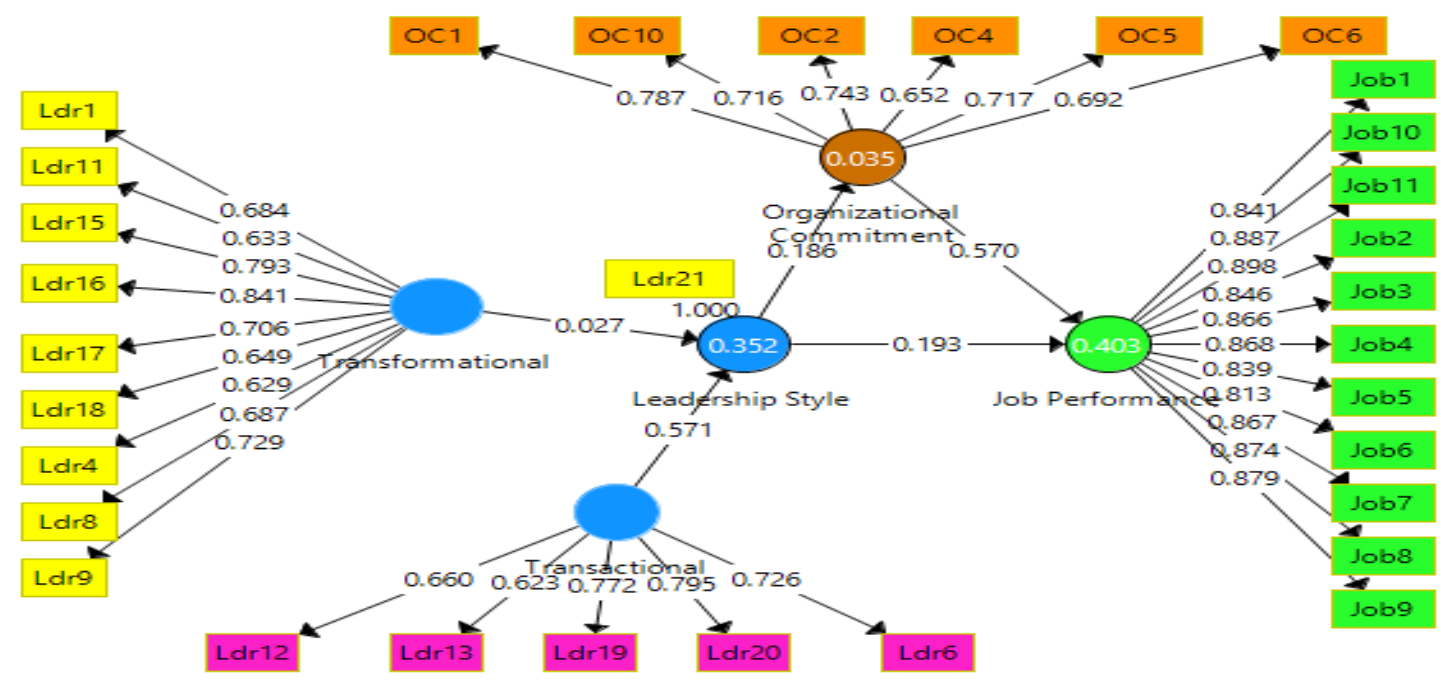

Fig. 2: PLS Algorithm of Job Performance

The results of the bootstrapping with $t$ values $>1.96(p=0.05)$ indicate the significance of the relationships between the exogenous variables (organizational commitment and leadership style) with the endogenous variable (job performance). The results in Table 1 indicate that the relationships between organizational commitment and with job performance, leadership style with organizational commitment and transformational leadership style with leadership style are significant at a level of 5\% probability of error as all the $t$ values are $>1.96$ threshold value. However, the relationship of leadership style with organizational commitment and transformational leadership with leadership style is not significant with $t$ value of 1.352. The results is in line with the study done by Kamarularif [56] who concluded that leadership style and organizational commitment has a positive significant relationship toward job performance. The result supports the research by Ying, Zaman and Ahmad and Yiing [13] who derived at the findings of leadership style as one of the critical factors that influence organizational commitment. Similarly, it is consistent with the results of the research by Putriana [47] that determined organizational commitment as important determinants of job performance. It also concurs with Wen \& Chiou [57] who have stated organizational commitment is the most crucial and personal variable influencing performance. However, there is significant relationship between organizational commitment and job performance with $t=7.633$. Also, there is significant relationship between leadership styles with job performance whereby the $t$ value is 2.139 . Amongst the two predictive constructs, organizational commitment $(\beta=$ 0.570 ) has better effect in predicting job performance compared to leadership style. The results show that organizational commitment $(\beta=0.570)$ has the highest direct effect on the measure of job performance and it has also the highest total effects on job performance as compared to leadership style ( $\beta=0.299)$. The results concur with the study done by Chughtai et al., [58] that organizational commitment is positively related to job performance. The findings of other studies indicated that organizational committed employees are more likely to have higher job performance [42-43, 59-60]. The results of the total effect indicate that the construct of organizational commitment on job performance is substantially higher than leadership style. Practically, the results indicate that increasing the amount of effort in enhancing the leadership style of its personnel will certainly improve its job performance.

Table 1: Significance of the Relationships between Variables

\begin{tabular}{llll}
\hline Construct & Path & t Value & Construct \\
& Coefficient & $(>1.96)$ & \\
\hline Leadership Style -> Job Performance & 0.193 & 2.407 & Significant \\
Leadership Style -> Organization Commitments & 0.186 & 1.445 & Not Significant \\
Organization Commitments -> Job Performance & 0.570 & 7.973 & Significant \\
Transformational -> Leadership Style & 0.027 & 0.158 & Not Significant \\
Transactional -> Leadership Style & 0.571 & 3.026 & Significant \\
\hline
\end{tabular}

The importance-performance matrix analysis (IPMA) was used to extend the results of PLS-SEM by taking the performance of each construct to draw conclusions on its performance and the relative importance of constructs in explaining other constructs in the structural model. The extension builds on the PLSSEM estimates of the path model relationships and adds an additional dimension to the analysis that considers the latent variables' average values [53]. IPMA contrasts the job performance structural model total effect (importance) and the average values of the latent variable scores (performance) to highlight significant areas for improvement for the organizational commitment and leadership style aspects so as to improve the job performance. Based on these results, with the same organizational commitment of its personnel, the Malaysian Army can focus its effort on improving the leadership style aspect of its personnel in order to augment its job performance. The graphical IPMA representation of job performance model is as depicted in Figure 3. 


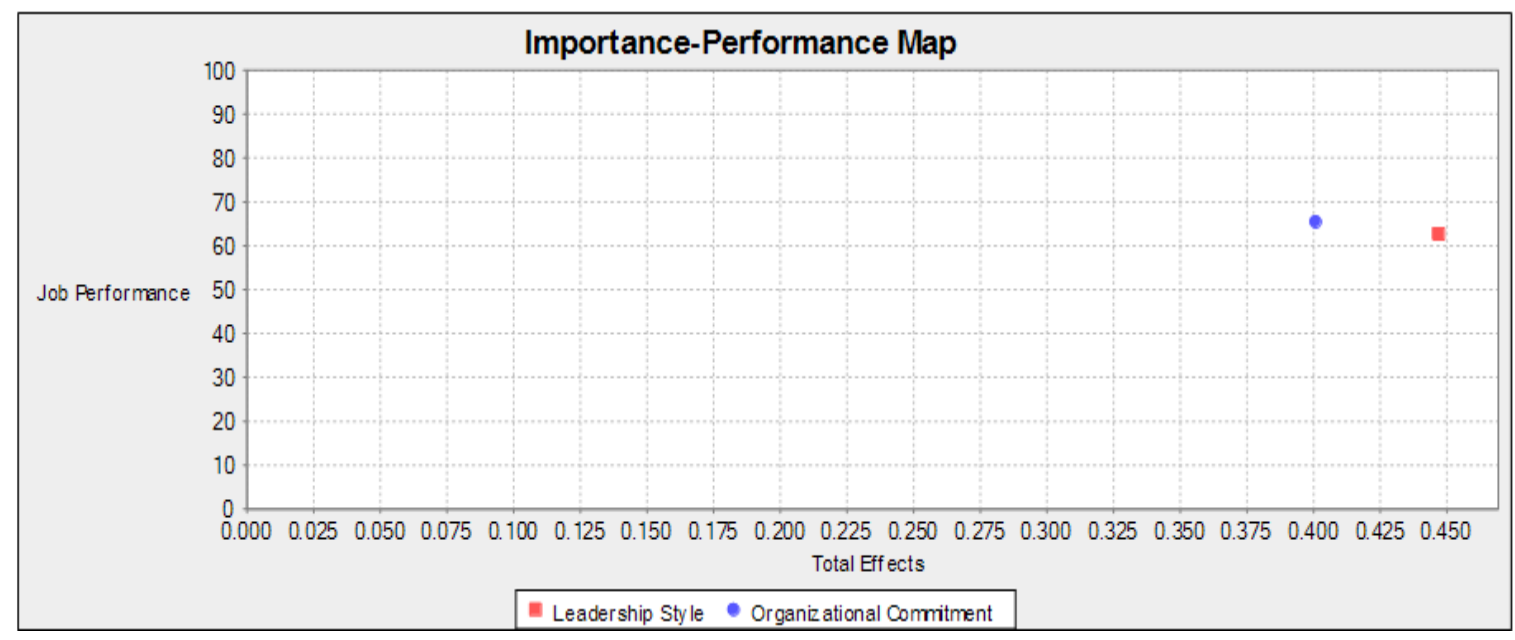

Fig. 3: Graphical IPMA representation of job performance model

The hypotheses testing for this research yielded the results as shown in Table 2. The results show that leadership style and organizational commitment are the two main factors affecting the job performance of the SNCOs in the combat support corps in the Malaysian Army. However, there is no mediation role played by organizational commitment for the relationship between leadership styles and job performance.

Table 2: Results of the Hypotheses Testing

\begin{tabular}{|c|c|c|c|c|}
\hline $\mathrm{H}$ & Hypothesis Statement & Results & & Results on Hypothesis \\
\hline $\mathrm{H}_{1}$ & $\begin{array}{l}\text { Leadership style of SNCOs has a positive relationship with job performance in the } \\
\text { combat support corps of the Malaysian Army }\end{array}$ & $\begin{array}{l}\text { Path coeff } \\
0.193\end{array}$ & $\mathrm{t}=2.139$ & Supported \\
\hline $\mathrm{H}_{2}$ & $\begin{array}{l}\text { Leadership style and organizational commitment contributes to the job performance } \\
\text { of SNCOs in the combat support corps of the Malaysian Army }\end{array}$ & $\mathrm{R}^{2}=.403$ & & Supported \\
\hline $\mathrm{H}_{3}$ & $\begin{array}{l}\text { Organizational commitment has a positive relationship with job performance of } \\
\text { SNCOs in the combat support corps of the Malaysian Army }\end{array}$ & $\begin{array}{l}\text { Path coeff }= \\
0.570\end{array}$ & $t=7.633$ & Supported \\
\hline $\mathrm{H}_{4}$ & $\begin{array}{l}\text { Organizational commitment has a mediating relationship between leadership style } \\
\text { and job performance in the combat support corps of the Malaysian Army }\end{array}$ & $\begin{array}{l}\text { Path coefficien } \\
=0.186\end{array}$ & $\mathrm{t}=1.352$ & Not supported \\
\hline $\mathrm{H}_{5}$ & $\begin{array}{l}\text { Transformational leadership has a stronger relationship than transactional leadership } \\
\text { towards leadership style of SNCOs in the combat support corps of the Malaysian } \\
\text { Army }\end{array}$ & $\begin{array}{l}\text { Path coeff }= \\
0.027 \text { and } \\
0.571 \text {. }\end{array}$ & $\begin{array}{l}\mathrm{t}=0.158 \text { and } \\
3.009\end{array}$ & Not Supported \\
\hline $\mathrm{H}_{6}$ & $\begin{array}{l}\text { Leadership style has a positive significant relationship with organizational } \\
\text { commitment of SNCOs in the combat support corps of the Malaysian Army }\end{array}$ & $\begin{array}{l}\text { Path coeff } \\
0.186\end{array}$ & $\mathrm{t}=1.352$ & Not Supported \\
\hline
\end{tabular}

Conclusion:

This research has established the relationship between leadership styles and job performance of SNCOs. Though there were positive relationship between these two variables, the relationship is not significant. Also, the research found that the relationship between organizational commitment and job performance was positively significant. However, there is no mediation role played by organizational commitment. These results will be instrumental in the Malaysian Army to study the reasons on why transactional leadership is pertinent among SNCOs. Military doctrines can be carved to assist the SNCOs in their strengths and weaknesses in their job performance. Current doctrines need to be re-looked to meet the current requirements especially from the view of the younger soldiers of $\mathrm{Y}$ generation joining the military. The research focused only on the job performance of the SNCOs in the combat support corps in the Malaysian Army. As the SNCOs are found in the various corps in the Malaysian Army, further research should be done on job performance that incorporate the SNCOs of the whole Malaysian Army. Research should also be conducted on the perception of SNCOs towards JNCOs in the same variables to identify and determine the leadership style, organizational commitment and job performance of the JNCOs. This is relatively important as the future middle managers will be derived from this group of soldiers to lead their units. Another research to be considered is the perception of SNCOs towards their officers in these three variables as to determine their leadership style, organizational commitment and their job performance.

\section{REFERENCES}

[1] Britt, T.W., C.A. Castro, A.B. Adler, (Eds). 2006. Military life: The psychology of serving in peace and combat (Vol 1): Military performance. Westport,CT: Prager Security International.

[2] Driskell, J.E. and E. Salas, 1996. (Eds). Stress and human performance. Mahwah, NJ: Lawrence Erlbaum Associates.

[3] Hancock, P.A. and J.L. Szalma, (Eds). 2008. Performance under stress. Burlington, VT: Ashgate Publishing.

[4] Campbell, J.P., R.A. McCloy, S.H. Oppler and C.E. Sager, 1993. A theory of performance. In N. Schmitt \& W.C Borman (Eds), Personnel selection in organizations (pp.35-70), San Francisco: Jossey-Bass.

[5] Borman, W.C. and S.J. Motowidlo, 1993. Expanding the criterion domain to include elements of contextual performance. In N. Schmitt \& W.C Borman (Eds), personnel selection in organizations (pp.71-98). San Francisco: Jossey-Bass

[6] Sackett, P.R., S. Zedeck and L. Fogli, 1988. Relations between measures of typical and maximum job performance. Journal of Applied Psychology, 73: 482486.

[7] Utecht, R.E. and W.D. Heier, 1976. The contingency model and successful military leadership. The Academy of Management Journal, 19(4): 606-618.

[8] Bass, B.M. and R.E. Riggio, 2006. Transformational Leadership, Lawrence Erlbaum Associates Publishers, London.

[9] Dionne, S.D., J.U. Chun, C. Hao, A. Serban, F.J. Yammarino and W.D. Spangler, 2012. Article quality and publication impact via levels of analysis incorporation: An illustration with transformational/charismatic leadership. Leadership Quarterly, 23(6): 1012-1042.

[10] Barbuto, J.E., 2006. Taking the charisma out of transformational leadership. Journal of Social Behaviour and Personality, 12(3): 689-690.

[11] Luftman, J., 2004. Managing the IT Resource: Leadership in Information Age, Prentice Hall. Malaysian Army (2012). Human Resources Doctrine Manual, Kuala Lumpur: Headquarters Training and Doctrine Command.

[12] Ivey, G.W. and T.J.B. Kline, 2010. Transformational and active transactional leadership in the Canadian military. Leadership \& Organizational Development Journal, 31(3): 246-262. 
Citation: S. Inderjit, Kwong, F.W., Jessica Ong Hai Liaw and Norlaila Mazura Hj. Mohaiyadin, 2018. Impacts of Leadership Styles and Organizational Commitment towards Job Performance in the Malaysian Army. Advances in Natural and Applied Sciences., 12(7): 4-9.

[13] Ying-Cheng Hung, Tsung-Ying Tsai \& Yu-Fen Wu, 2015. The effects of ethical work climate on organizational commitment in Taiwanese Military units, Chinese Management Studies, 9(4): 664-680.

[14] Hardy, L., C.A. Arthur, G. Jones, A. Shariff, K. Munnoch, I. Isaacs and A.J. Allsopp, 2010. The relationship between transformational leadership behaviors, psychological, and training outcomes in elite military recruits, The Leadership Quarterly, 21(1): 20-32

[15] Amna Yousaf, Huadong Yang \& Karin Sanders, 2015. Effects of intrinsic and extrinsic motivation on task and contextual performance of Pakistani professionals, Journal of Managerial Psychology, 30(2): 133-150.

[16] Walumbwa, F.O., B.J. Avolio and W. Zhu, 2008. How Transformational Leadership Weaves Its Influence on Individual Job Performance: The Role of Identification and Efficacy Beliefs. Personnel Psychology, 61(4): 793-825.

[17] Tremblay, M.A., 2010. Fairness perception and trust as mediators on the relationship between leadership style, unit commitment, and turnover intentions of Canadian forces personnel. Military Psychology, 22: 510-523.

[18] Kane, T.D. and R.T. Tremble, 2010. Transformational leadership effects at different levels of the Army, Military Psychology, 12(2): 137-60.

[19] Bass, B., 1990. Bass and Stodgill“"s Handbook of Leadership. New York: Free Press.

[20] Chan, Soh and Ramaya, 2011. Military Leadership in the 21st Century, Science and Practice, Cengage Learning.

[21] Dewettick, K. and M. Ameijde, 2011. Linking leadership empowerment behaviour to employee attitudes and behavioural intentions: Testing the mediating role of psychological empowerment. Personnel Review, 40(3): 284-305.

[22] Lewin, K., 2012. The impact of interpersonal environment on burnout and organizational commitment. Journal of Organizational Behaviour, pp: 123-144.

[23] Huy, Q., 2011. How middle managers' group-focus emotions and social identities influence strategic implementation. Strategic Management Journal, 32: $1387-140$.

[24] Li, Y.C., 2004. Examining the effect of organization culture and leadership behaviours on organizational commitment, job satisfaction, and job performance at small and middle-sized firms of Taiwan, Journal of American Academy of Business, 5(1/2): 432-8.

[25] Campbell, D., G. Dardis and K. Campbell, 2003. Enhancing incremental influence: a focused approach to leadership development. Journal of Leadership and Organizational Studies, 10(1): 29-44.

[26] Hough, L.M., F.L. Oswald and R.E. Ployhart, 2001. Determinants, detection and amelioration of adverse impact in personnel selection procedures: Issues, evidence and lessons learned. International Journal of Selection and Assessment, 9: 152 \pm 194 .

[27] Murphy, K. and J. Cleveland, 1995. Understanding performance appraisal: Social, organizational and goal-oriented perspectives. Newbury Park, CA: Sage.

[28] Northouse, P.G., 2007. Leadership theory and practice (4th ed). Thousand Oaks, CA: Sage Publications.

[29] Jing, F.F. and G.C. Avery, 2008. Missing Links in Understanding the Relationship between Leadership and Organizational Performance. International Business \& Economics Research Journal, 7(5): 67-78.

[30] Bass, B.M. and Riggio, 2006. Improving Organizational Effectiveness Through transformational Leadership, Sage Publications, Thousand Oaks, CA.

[31] Bolden, R., J. Gosling, A. Marturano and P. Dennison, 2003. A Review of Leadership Theory and Competency Frameworks [On-line]. Retrieved 15 May 2012 from http://www.leadershipstudies.com/documents/mgmt_standards.pdf

[32] Bass, B.M. and B.J. Avolio, 2004. Multifactor Leadership Questionnaire, 3rd ed: Manual and Sampler Set. Redwood City, CA: Mind Garden, Inc.

[33] Burns, J.M., 1978. Leadership. NewYork: Harper \& Row Publisher.

[34] Bass, B.M., 1985. Leadership and Performance beyond Expectations, New York: Free Press.

[35] Politis, J.D., 2002. Transformational and transactional leadership enabling (disabling) knowledge acquisition of self-managed teams: the consequences for performance. Leadership \& Organization Development Journal, 23(4): 186-197.

[36] Bass, B.M., B.J. Avolio, D.I. Jung and Y. Berson, 2003. Predicting unit performance by assessing transformational and transactional leadership, Journal of Applied Psychology, 88(2): 207-218.

[37] Sadler, P., 2003. Leadership (2nd. Ed.). London: Kogan Page.

[38] Yukl, G.A., 2010. Leadership in Organizations, (7th Ed). Upper Saddle River, NJ.

[39] Mowday, R., L. Porter and R. Steers, 1979. The Measurement of organizational commitment, Journal of Vocational Behaviour, 14(2): 224-247.

[40] Hackett, R.D., D. Wang and Z.X. Chen, 2011. Leader-member exchange as mediator of the relationship between transformational leadership and followers' performance and organizational citizenship behaviour, Academy of Management Journal, 48(3): 420-432.

[41] Allen, N.J. and J.P. Meyer, 1990. The Measurement and Antecedents of Affective, Continuance and Normative Commitment to the Organization, Journal of Occupational Psychology, 63: 1-18.

[42] Abdul Rashid, Sambasivan, M. and J. Johari, 2003. The influence of corporate culture and organizational commitment on performance. Journal of Management Development, 22(8): 708-728.

[43] Chen, J., C. Silverthorne and J. Hung, 2006. Organization communication, job stress, organizational commitment, and job performance of accounting professionals in Taiwan and America. Leadership \& Organization Development Journal, 27(4): 242-249.

[44] Meyer, J.P. and N.J. Allen, 1991. A three-component conceptualization of organizational commitment. Human Resource Management Review, 1(1): 61-89. Retrieved May 1, 2007, from EBSCO Host MasterFile Premier database.

[45] Meyer, J.P. and N.J. Allen, 1997. Links between work experience and organizational commitment during the first year of employment: A longitudinal analysis, Journal of Occupational Psychology, 61(3): 195-209.

[46] Robbins, S.P. and Judge, 2013. Organizational Behaviour. Ed. 15. NJ : Pearson Education

[47] Putriana, 2015. International Journal of Education and Research, 3: 9

[48] Solinger, O.N., W. van Olffen and R.A. Roe, 2008. Beyond the three-component model of organizational commitment. Journal of Applied Psychology, 93(1): 70-83.

[49] Fu, W. and S.P. Deshpande, 2014. The Impact of Caring Climate, Job Satisfaction, and Organizational Commitment on Job Performance of Employees in a China's Insurance Company. Journal of Business Ethics, 124(2): 339-349.

[50] Akdogan, A.A. and O. Demirtas, 2015. "The effect of ethical leadership behavior on ethical climate, turnover intention, and affective commitment", Journal of Business Ethics, 130(1): 59-67.

[51] Moriarty, K.O., R.C. Campbell, T.S. Heffner and D.J. Knapp, 2009. Investigations into Army enlisted classification systems (Army Class): Reclassification test and criterion development report (FR 08-54). Alexandria, VA: Human Resources Research Organization.

[52] Mowday, R., R. Steers and L. Porter, 1982. "The measurement of organizational commitment”, Journal of Vocational Behavior, 14(2): 224-247.

[53] Hair, J.F., Hult, Tomas M., Ringle and Sarstedt, 2014. A Primer on Partial Least Squares Structural Equation Modelling (PLS-SEM), SAGE Publishing Inc.

[54] Hair, J.F., M.A. Wolfinbarger Celsi, H. Money, P. Samouel and M.J. Page, 2011. Essentials of business research methods. Armonk, New York.

[55] Henseler, J., C.M. Ringle and R.R. Sinkovics, 2009. The use of partial least squares path modelling in international marketing. Advances in International Marketing, 20277-320.

[56] Kamarularif Bin Ramli, 2009. The relationship between leadership style and organizational commitment towards job performance in the 12th Malaysian Infantry. (Unpublished Masters Degree), University Malaya, Kuala Lumpur.

[57] Wen \& Chiou (2009). The third Asian Conference on Education 2011.Official Proceedings, Osaka. Japan 538.

[58] Chughtai et al.,(2006).Antecedents and consequences of Organizational Commitment Among Pakistan University Teachers, Applied H.R.M. Research,11(1),39-64

[59] Samad, S., 2005. Unraveling the organizational commitment and job performance relationship: Exploring the moderating effects of job satisfaction, The Business Review, Cambridge, 4(2): 79-84.

[60] Yukl, G.A., 2010. Leadership in Organizations, (7th Ed). Upper Saddle River, NJ. 